\title{
REPEATITION AS A STYLISTIC DEVICE OF EXPRESSION IN E. PO POETIC SPEECH
}

\section{Ivanchenko M. Yu.}

\section{INTRODUCTION}

The work of the American poet and writer Edgar Allan Poe is of great interest to literary scholars and translators around the world. His contribution to world literature is unquestionable; his ideas still influence world culture.

The iconic figure of world literature, the series of new genres founder, the first professional writer of America, a master who incomprehensibly combined poetic genius and mathematical harmony, a knight of logic, wandering in the labyrinths of the unconscious, a man whose work occupied little contemporaries and will forever remain in the memory of his descendants.

World fame and recognition, which Poe received, alas, already after death, give rise to a misleading view of him as a prolific author. Meanwhile, he wrote quite a bit. The poetic canon of Po includes a little more than fifty works, among which we find only two relatively long poems - "Tamerlan" and "Al Aaraaf". The rest are relatively small lyric poems of various denominations. Thomas Eliot once remarked that of all the poetic works of Edgar Allan Poe, "only half a dozen were truly successful. However, not a single poem, not a single poem in the world had a wider circle of readers and settled so firmly in people's memory than these few poems by Po"".

His "Philosophy of Composition" (1846) confirms that in his poetry, when creating images and the entire artistic structure of the poetic work, E. Poe proceeded not from fiction, but based on reality, theoretically substantiating the need for a romantic expression of the beauty of life.

One of the main aesthetic theses, which he constantly adhered E. Po to is the statement that: "If the first phrase does not contribute to the achievement of a single effect, it means that the writer failed from the very beginning. According to his opinion there should not be a single word in the entire work that would not directly or indirectly lead to a single purpose conceived. So, carefully and skillfully, finally, a picture is created

\footnotetext{
1 Зырянова Т. Средства создания звуковой экспрессии. Зеленая лампа. 2004. № 1. URL: http://lamp.semiotics.ru/express.htm (дата звернення: 27.09.2019)
} 
that gives the one who contemplates it a feeling of the most complete satisfaction",

The general principle of poetry by Edgar Allan Poe lies in the focus on the emotional and psychological impact of any work. He called such an effect a "totality effect", the most important feature of which was unity. It is the "total effect" that all aspects of poetic creation, all the particular principles of its organization, must be subordinated to.

Edgar Poe's poetry has only one subject - beautiful, widely understood. Sources of beauty for the poet are three spheres of life: nature, art and the world of human relations, taken, however, in a relatively narrow spectrum. The poet is attracted only by relationships arising as an emotional derivative of love and death.

The purpose of this research is to analyze the using of repetitions in E. Poe's poems.

In order to achieve this aim we are going to set the following tasks: to explore E.Poe's poetic heritage; to define the main characteristics of syntactical-stylistic device repetition; to analyze the poems of E. Poe; to explore the use of different kinds of repetitions in E. Poe's poems.

\section{Repetition as a syntactical stylistic device: general notion}

Speech expression is inherent not only to sounds, words and their grammatical forms, but also to a greater extent syntactic organization of speech. The style of any language is defined by syntax. Syntactic organization of speech is the main means of expression. As it is known, sentences are the main mechanism of text production. It is through a sentence that new information is conveyed in the text as it is unfolded. Any sentence in the text has the ability to communicate with other sentences. Lexicon, vocabulary, grammatical means are involved in the implementation of this connection. The orderliness of kind and temporal, modal and spatial meanings in sentences, the nature of the themerheumatic articulation performs the integrating functions in the text. The basic unit of the syntactic level is the sentence model, which is understood as a predicative chain of word forms that are in a certain linear sense and formal relations ${ }^{3}$.

Even Aristotle's rhetoric carefully classified the special techniques of syntactic organization of public speaking - figures that contributed to its influence on the listener ${ }^{4}$. Consideration rhetorical figures and their

\footnotetext{
${ }^{2}$ Poe E. A. The Works of the Late Edgar Allan Poe. Vol III. New York: J.S. Redfield, Clinton Hall, 1850.

3 Арнольд И.В. Стилистика. Современный английский язык:Учебник для вузов [Текст]. 5-е издание, вып., дополн. М.: 2002. Ст. 215.

${ }^{4}$ Ars Rhetorica. Edited by W. D. Ross. OCT. Oxford: Oxford UP: 1959.
} 
classification based on grouping into in accordance with the deviations from the norm presented in them aims to understand more deeply the essence of the phenomenon and functioning of syntactic stylistic means of speech.

The role of repetition in the construction of text of different genres studied in the writings of various linguists [Propp 1954; Likhachev 1967; Lotman 1972; Lukyanova 1982; Plekhanov 1983; Danilevskaya 1985; Cheremisina, Novikov 1996; Novikov 1997 and etc.]. However, repetition is not always rated as constructive element of text construction. M.P. Senkevich defines replication constructs as a violation of connectivity words ${ }^{5}$, and $\mathrm{H}$. Casares considers the constructions of pleonasm deviations from the norm of construction $^{6}$. Other linguists have concluded that there are reasons for recurrence related to the main function of language is to be a means communication because the repetition of the utterance is related to the need for the speaker to convey the thought to the listener, to impose it opinion. Again, redundancy can help the recipient better understand what is being said in case of unnecessary noise impede successful communication.

Concerning this connection English linguist K. Weils, editor-in-chief of "A Dictionary of Stylistics", believes that the repetition, which appears as vivid display of language skills, under certain conditions, namely when "noise" interfere with good communication, is communicatively motivated ${ }^{7}$.

When considering the role of repetitions in the text, they are always noted function of communication, their participation in formation of coherence of the text. The development of a microtome is accomplished by contact repetition - a pick that performs meaningful and structural function. Repetition-delight - highlights significant fragments of the text, on the one hand, promote connectivity text and delimiting micro themes on the other hand. Great value for coherence (lexical-semantic unity) the text is based on the principle of isotopy, the basis of which is semantic repetition that performs expressive gain, gradation or refinement, is a striking stylistic technique. Another important type for a text organization repetition is syntactic concurrency because it sets in the text of the relation of a special kind of semantic equivalence ${ }^{8}$. Text repetitions serve as a development thoughts and accordingly the development of semantic text space.

\footnotetext{
${ }^{5}$ Сенкевич М. П. Стилистика научной речи и литературное редактирование научных произведений. М.: Высшая школа, 1984. Ст. 205.

${ }^{6}$ Касарес Х. Введение в современную лексикографию. М., 1959. Ст. 350.

${ }^{7}$ Weils K. A. A Dictionary of Stylistics. London, 1997. P. 395.

${ }^{8}$ Коробейникова О. Ю. Языковая эквивалентность текста как фактор организации художественного текста. дис. ... канд. филол. наук : 10.02.01 «Русский язик». СПб., 1996. Ст. 32.
} 
Repetitions not only reinforce the text, but also make it work dynamic ${ }^{9}$. Thanks to repetitions, an overall idea is created, there is a repetition a specific code that switches to one subject to another, which is intended by the author of the text minor. Repetition creates another effect: it is a background where other text semantic elements stand out more vividly, since the reader is primarily attracted by the new information, and already known, is the background necessary for better perception of new material.

The principle of repetition is evident at all levels of text organization. Text is a complex language sign that has different sides (aspects) denotative, significative, connotative. However, the text may show dominance one aspect. If denotative prevails in the text paradigms (documentary texts), then the names of important objects are repeated leading to highlighting the main content of the text. With more Significant values (scientific texts) are important explaining the meaning in the form of logically related conclusions. At the domination of the connotative aspect seems significant revealing of the inner spiritual nature, feelings and experiences event participants. An example of a unit of this kind would be a repetition that serves to characterize a character's speech and his emotional state.

\section{Repetition in E. Poe's poem "The Bells"}

"The Bells" was written by Poe in 1848, but it was not published until December, 1849, some three months after his death ${ }^{10}$. It is an irregular ode comprised of four numbered movements that vary in length, each one longer than its predecessor, each dedicated to a successive stage in the human life span, and each having its own type of metal bell. The poem is filled with alliteration, assonance and monosyllabic rhymes, and the reader cannot help but be struck by the sheer pace of its rapid lyrical flow.

In "The Bells", a morbid poem by Edgar Allan Poe, the author masterfully captures the vicious cycle of humanity through expressive diction and sounds to appeal to the reader's schema throughout all four stanzas of the poem. Through careful use of diction, Poe is able to capture the cycle of human life. Throughout all of the stanzas, Poe places words that allow the reader to visualize that particular section of life ${ }^{11}$.

\footnotetext{
${ }^{9}$ Leech G. Short M. Style in fiction: a linguistic guide to English fictional prose/ London : Longman, 1981. P. 323.

${ }^{10}$ Ситников К. Симфония колоколов и колокольчиков: [стихи Э.А. По «Колокола» в рус. пер.]. Литературная учеба. 2000. № 1. Ст. 210.

${ }^{11}$ Колчева Т.В. Мистицизм поэтического ритма Эдгара По в восприятии К. Бальмонта: (На основе анализа стихотворения Э. По «Тhe Bells» и перевода К. Бальмонта «Колокольчики и колокола»). Русский символизм и мировая культура. М., 2004. Вып. 2. Ст. 70.
} 
The first stanza represents childhood with words such as "oversprinkle", "twinkle", and "delight". Three times in this stanzas Edgar Poe uses simple verbal repetition, palilogiain. For the first time, as the characteristic of "silver bells": "How they tinkle, tinkle, tinkle", in order to emphasize on their sizes and beauty, compairing them with the child small and pretty. For the second time, the palilogiain is used in order to remind the reader about the passing time: "Keeping time, time, time, in a sort of Runic rhyme". For the last time the repetition of the same word is used in the prelast line: "From the bells, bells, bells, bells, bells, bells, bells". Repetition of the word bells emphasizes the constant ringing and increasing distress that the bells bring.

They convey a sense of lightness and preciousness which activates the reader's schema towards childhood. Also in the first stanza through the alliteration (using w's and m's), Poe highlights childhood and realizes, "What a world of merriment their melody foretells", as if implying that the person still has a whole life ahead of them as children do. Along with diction, there are also many sounds that Poe uses to represent childhood. The last line of the stanza summarizes the feeling and expression of the entire stanza, the impression is intencisied through the usinf of homoiptoton. Childhood can be expressed, "From the jingling and the tinkling of the bells".

The second stanza also contains diction and sounds but this time to represent the glory when a person is in prime condition both mentally and physically. Words that convey a feeling of happiness, wealth, and grandeur are used repeatedly in this stanza. Through the assonance, the long "o": "molten - golden notes"; short "i": "What a liquid ditty floats " a sense of great enjoyment of life and where perfect is not too far away is painted into the reader's mind. Poe is able to capture the grandiose golden years of life by emphasizing on "the Future!" and "the rapture that impels". By using "rapture", Poe brings forth the feeling of ecstatic joy towards this grand period of life. Poe also uses homoiptoton (the repetition of the same endings) in order to reveal to the reader that all aspects of this part of life fit together like a good rhyme:

Oh, from out the sounding cells,

What a gush of euphony voluminously wells!

How it swells!

How it dwells

On the Future! - how it tells

Of the rapture that impels

To the swinging and the ringing

Of the bells, bells, bells - 
The swing exemplifies harmony which is appropriate in that this part of life runs like a well-oiled machine.

In the third stanza, the circumstances and quality of life start to decline. The mind begins to dull and the power and might of the body starts to fade. The words that Poe uses are "terror", "despair", and "turbulency". Calamity and turbulence fills the air as the golden years begin to fade and the fear of the inevitable bring frustration and sadness. The inner conflict that is experienced is exposed through the sounds of "clamor", "clanging", "roar". Alliteration adds music of its own and frighten the reader: t's - "What a tale of terror, now, their turbulency tells!"; f's - "In a mad expostulation with the deaf and frantic fire" ; d's "With a desperate desire"; c's - " How they clang, and clash, and roar!"; s's - "How the danger sinks and swells, by the sinking or the swelling in the anger of the bells". In this line the polyptoton, "sinks and swells, by the sinking or the swelling", is used to attract the attention of the reader to the approaching danger.

It seems that this part of life leads man into denial against the fallen status of both his mental and physical capabilities, the absence of which is accented with the help of palilogiain, which characterize the brazen bells: "They can only shriek, shriek"; "Leaping higher, higher, higher, with a desperate desire"; the last chance "Now - now to sit, or never".

Another striking examples of using repetition in revealing the thoughts of the author are observed in this stanza.

Yet the ear, it fully knows,

By the twanging

And the clanging,

How the danger ebbs and flows;

Yet, the ear distinctly tells,

In the jangling

And the wrangling,

How the danger sinks and swells...

Anaphora, Yet the ear, made an accent on the part of the body, which perceives the sounds of bells, the sounds of danger. Homoiptoton, "ing", emphasizes the quality of the constant ringing of the bells, and, so adds music to this stanza.

In the fourth and final stanza, man has resigned against fate and has accepted what is to be the inevitable as all power dissolve from the once mighty body and activity in the mind slows down to a minimum: "Hear the tolling of the bells - iron bells!". Man becomes "solemn", "melancholy", and develops "rust within their throats". The atmosphere of melancholy and fear in front of the end of life, death, is revealed through 
the alliteration: m's - "At the melancholy meaning of their tone!"; "In that muffled monotone"; th's - "From the rust within their throats"; h's - "On the human heart a stone"; assonance - "And he dances, and he yells". In some cases the homoiptoton is used to imitate the sound of bells:

To the throbbing of the bells -

Of the bells, bells, bells -

To the sobbing of the bells:-

To the rolling of the bells-

Of the bells, bells, bells:-

To the tolling of the bells -

It's obvious to the reader that man is expiring and perhaps even rusty from inactivity. The author wants us to note the words "tolling", "rolls", "time", and "knells". To achieve this aim he uses palilogiain: "And who, tolling, tolling, tolling"; "And he rolls, rolls, rolls, rolls, rolls"; "As he knells, knells, knells". All these words denote the types of the (bell) sounds, which are produced when somenone is dead. Edgar Poe reminds us about the passing time through the isocolon, the sentence with the palilogiain, "Keeping time, time, time", which is used three times in this stanza. It is to mention, that two lines of the fourth part of this poem, which are repeated twice "Keeping time, time, time, in a sort of Runic rhyme" is a repetition from the first stanza, that, to our mind, form some kind of frame to produce the connection within the poem. In the philosophical sense it reminds us about the changeability of life, today you are young, and tomorrow - already old, suggesting the finality of death. For the third time this quotation is repeated a little transformed: "Keeping time, time, time, as he knells, knells, knells, in a happy Runic rhyme", it means that some people die (knells, knells, knells - "the sound of a bell being rung slowly because someone has died"12 and the other - born, and live their ordinal life (in a happy Runic rhyme). E.Poe addresses his poem to people, he fixes the readers attention on it, that's why he uses palilogiain; "And the people - ah, the people"; and anaphora:

They are neither man nor woman-

They are neither brute nor human-

which is used to make an emphasis on the words "man", "woman", "brute", "human". We consider, that he tries to explain the inevitability of death for everyone, independently of status.

In the last few lines of this final stanza, the poem is digressing and droning on and on much like old age brings: "To the moaning and the

12 Cambridge Idioms Dictionary (2006), $2^{\text {nd }}$ ed. Cambridge University Press. Retrieved from: http://www.cambridge.org 
groaning of the bells" (assonance of the "oa"). All of the activity is winding down and life seems to finally be ending.

No one is exempt from participating in this cycle of being born, living, and eventually dying. All life is subject to this rule set in stone in eternity past from whence life appeared and unto eternity future. As Anais Nin once said, "Life is a process of becoming, a combination of states we have to go through"13.

\section{Repetition as a Way of Reavhing Expressiveness in E. Poe poems "Anabel Lee", "For Annie", "Alone", "To Helen"}

Famous E.Poe's poem "Annabel Lee" was published on October 9, 1849, in the New York Daily Tribune ${ }^{14}$.

The theme of this is eternal love. The love between the narrator and Annabel Lee is so strong and beautiful and pure that even the seraphs, the highest order of angels in heaven, envy it. They attempt to kill this love by sending a chilling wind that kills Annabel Lee ${ }^{15}$. However, the love remains alive-eternal-because the souls of the lovers remain united. The death of a beautiful woman is a common theme in Poe's writing.

Like Shakespeare's Romeo and Juliet, the narrator and Annabel Lee are both very young when they fall deeply in love. In addition, like Shakespeare's "star-crossed" lovers, Poe's lovers become victims of forces beyond their control ${ }^{16}$. Finally, the narrator and Annabel Lee-like Romeo and Juliet-experience a love beyond the understanding of older persons.

The model for Annabel Lee was probably Poe's wife, Virginia Clemm, whom he married when she was only 13 . Their marriage was a very happy one. Unfortunately, she died of tuberculosis in January 1847 when she was still in her twenties. Poe died two years and nine months later-on October 7, 1849. "Annabel Lee" was his last poem ${ }^{17}$.

Poe uses not only rhyme and rhythm but repetition in "Annabel Lee", to create a harmony of sounds that underscore the exquisite harmony of the narrator's relationship with his beloved ${ }^{18}$.

\footnotetext{
13 Ситников К. Симфония колоколов и колокольчиков : [стихи Э.А. По «Колокола» в рус. пер.] Литературная учеба. 2000. № 1. Ст. 220.

${ }_{14}$ Михина М.В. Эдгар Аллан По, новеллист, поэт, теоретик, и французская поэзия второй половины ХІХ века : автореф. дис. ... канд. филол. наук / МГУ им. М.В. Ломоносова. М., 1999. Ст. 5.

${ }^{15}$ Коноваленко А.Г. Баллады Э. По в переводе В. Брюсова: автореф. дис. ... канд. филол. наук / Том. гос. ун-т. Томск, 2007. Ст. 20.

${ }^{16}$ Коноваленко А.Г. Баллады Э. По в переводе В. Брюсова: автореф. дис. ... канд. филол. наук / Том. гос. ун-т. Томск, 2007. Ст. 18.

${ }^{17}$ Михина М.В. Эдгар Аллан По, новеллист, поэт, теоретик, и французская поэзия второй половины XIX века : автореф. дис. ... канд. филол. наук / МГУ им. М.В. Ломоносова. М., 1999. Ст. 10.

${ }^{18}$ Михина М.В. Эдгар Аллан По, новеллист, поэт, теоретик, и французская поэзия второй половины XIX века : автореф. дис. ... канд. филол. наук / МГУ им. М.В. Ломоносова. М., 1999. Ст. 12.
} 
The author uses repetition to create the rhyme. Throughout the poem, Poe repeats the soud of long "e". For example, in the first stanza, Line 2 ends with sea, Line 4 with Lee, and Line 6 with me.

It was many and many a year ago,

In a kingdom by the sea,

That a maiden lived whom you may know

By the name of Annabel Lee; -

And this maiden she lived with no other thought

Than to love and be loved by $\underline{\text { me. }}$.

The internal rhyme example, fulfilled with the help of homoiptoton, occurs in the last line of Stanza 4:

The angels, not half so happy in Heaven,

Went envying her and me;

Yes! that was the reason (as all men know,

In this kingdom by the sea)

That the wind came out of the cloud, chilling

And killing my Annabel Lee.

In Stanza 5:

And neither the angels in Heaven above

Nor the demons down under the sea

Can ever dissever my soul from the soul

Of the beautiful Annabel Lee:-

In the last Stanza:

For the moon never beams without bringing me dreams

Of the beautiful Annabel Lee;

Rhythmic patterns are repeated throughout the poem, perhaps to make the poem completed.

The refrain is created by repetition of such phrases as in this kingdom by the sea (in 1, 2, 3, 4 stanzas) and my Annabel Lee (or my beautiful Annabel Lee):

For the moon never beams without bringing me dreams

Of the beautiful Annabel Lee;

And the stars never rise but I see the bright eyes

Of the beautiful Annabel Lee;

In addition, E.Poe sometimes repeats words or word patterns within a single line, as in (1) many and many a year ago, (2) we loved with a love that was more than love, (5) my soul from the soul, and (6) my darling-my darling, (6) She was a child and I was a child. These words are repeated not only because of the rhythm, but because the author wants to attract our attention to the meaning of these words - soul, love, dream, darling, years, 
and child. They show the mood of the hero - agony, lament, amd deep sorrow for the loss. But he feels comforted when he knows that the forces of their love are stronger than of death, that their love is timeless.

Further E. Po uses the repetition of consonant sounds " $w$ " and "l" (alliteration): But we loved with a love that was more than love"; " $\mathrm{h}$ " - in th $4^{\text {th }}$ stanza: The angels, not half so happy in Heaven; " $b$ " in the $6^{\text {th }}$ : For the moon never beams without bringing me dreams, of the beautiful Annabel Lee.

Poe sometimes couples repetition of consonant sounds with repetition of vowel sounds, as in many and many, love and be loved, and those who were older than we. Especially striking examples of alliteration (s's) and assonance (i's) we find in the last stanza, as it was mentioned befor, at the emotional climax of the poetry, which the poet fulfill through these devices.

And so, all the night-tide, I lie down by the side

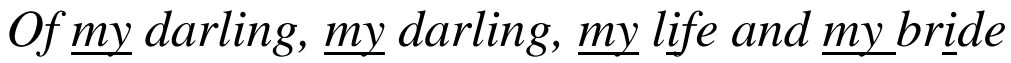

In her sepulchre there by the sea-

In her tomb by the side of the sea.

In the last two lines the poet uses anaphora and polysyndeton (four times 'my') in order to make us feel how he appreciates her, and to realize the depth of his sorrow.

In short, the unread atmosphere created by the author emphasizes the purity and innocence both of Annabel Lee and of the speaker's love for her, therefore it helps to arouse universal responses in all readers of all time and move them in a deep way - their love is so strong that even angels and demons cannot separate them. So the device adds to the idea of the everlasting love.

For Annie. Another popular poem "For Annie" was written for Nancy Richmond (whom Poe called Annie). Lady Richmond was a married woman and Poe developed a strong platonic, though complicated, relationship with her. The poem was first set to be published on April 28, 1849. In a letter dated March 23, 1849, Poe sent the poem he wrote to Richmond saying, "I think the lines 'For Annie' (those I now send) much the best I have ever written". Richmond would officially change her name to Annie after her husband's death in $1873^{19}$.

One of the most common technics of repetition in poetry is the frame, where the same line (or, once, even a stanza) is repeated at the beginning and ending of six poems. In general, such a pattern in Poe's poems follows, necessarily, a similar dialectical development. The first line presents a thesis statement or a point of reflection; the poem becomes a mediation upon or

${ }^{19}$ Complete Works of Edgar Allan Poe. Tally Hall Press, 1997. P. 987. 
illustration of the initial statement and by the end of the poem, returning where it has begun, we come to a fuller understanding of this line.

The Poe's "For Annie" begins with

All that we see or seem

Is but a dream within a dream.

The ten lines within this frame, a contemplation of the world illustrate the tone of these lines. The scene depicts the roaring sea, a surf-tormented shore, the golden sand, which is impossible to grasp, the disappointment of the hero. And it ends with the same two lines, but slightly modified, E.Poe changes statement into the question ${ }^{20}$ :

Is all that I see or seem

But a dream within a dream?

The inner contents elaborate and mediate upon the frame statement. In the conclusion we have a more complete understanding of the problem, the author can't believe, he hopes, that everything is not as bad as it seems to be, that's why he asks a question.

Edgar Allan Poe uses repetition to create the depressing atmosphere of the poem. He repeats words or word patterns within a single line, as in (2) Is but a dream within a dream; (7) How few! Yet how they creep; (9) While I weep - while I weep!

Anaphora in the $10^{\text {th }}$ and the $11^{\text {th }}$ lines:

While I weep - while I weep!

Oh, God! can I not grasp

Them with a tighter clasp?

Oh, God! can I not save

One from the pitiless wave?

These words dream, weep, God, how are repeated to attract our attention to the meaning of these words. E.Poe suppousely wanted to emphasize the hopelessness of the situation.

To intensifyt he impression, which poem produces on the reader, to imitate the sounds of the sea he uses alliteration.

Stanza 1: repetition of h's, g's, s's.

All that we see or seem

Is but a dream within a dream.

I stand amid the roar

Of a surf-tormented shore,

And I hold within my hand

Grains of the golden sand-

How few! yet how they creep

Through my fingers to the deep,

${ }^{20}$ Complete Works of Edgar Allan Poe. Tally Hall Press, 1997. P. 975. 
Stanza 2: w's, g's, s's, d's.

While I weep - while I weep!

Oh, God! can I not grasp

Them with a tighter clasp?

Oh, God! can I not save

One from the pitiless wave?

Is all that I see or seem

But a dream within a dream?

The atmosphere created by the author emphasizes the complexity of the relationships between people. It is impossible to solve this problem without God, while only He knows everything about us. Such problems are so common, that arouse universal responses in all readers of all time.

Alone. "Alone" is the most popular of Poe's early poems, one which was not intended for publication. It was written about 1829 in the album of a young female acquaintance. In manuscript, Poe gave the poem the simple designation of "Original", but it is now universally known as "Alone", beginning with lines which enshrine a personal sense of isolation, "From childhood's hour I have not been ..." It was first printed in 1876 in a slightly altered facsimile in Scribner's Magazine. After a certain amount of discussion about its authenticity, "Alone" has long been accepted - and is perhaps one of Poe's most revealing poems ${ }^{21}$.

The rhyme scheme used by Poe in this poem is described as AABB. The author uses homoioteleuton to conform to this rhyme scheme:

From childhood's hour I have not been

As others were; I have not seen

As others saw; I could not bring

My passions from a common spring.

E.A. Poe uses different types of repetition, one of them is anaphora. Six lines of the poem beginning with the same preposition "from", three lines from "as", two lines from personal pronoun "my". Through these repetitions the writer tries to express the depth of his feelings, he juxtaposes them to the different objects and phenomena of nature.

From childhood's hour I have not been

As others were; I have not seen

As others saw; I could not bring

My passions from a common spring.

From the same source I have not taken

$\underline{M y}$ sorrow; I could not awaken

$\underline{M y}$ heart to joy at the same tone;

${ }^{21}$ Complete Works of Edgar Allan Poe. Tally Hall Press, 1997. P. 974. 
To make an amphasis on his loneliness he uses palilogia: "And all I loved, I loved alone" ( $8^{\text {th }}$ stanza).

E.Poe widely uses alliteration, while this type of repetition adds richness to the poem. Note the H's, s's and p's in 1-8 lines:

From childhood's hour I have not been

As others were; I have not seen

As others saw; I could not bring

My passions from a common spring.

From the same source I have not taken

My sorrow; I could not awaken

My heart to joy at the same tone;

And all I loved, I loved alone.

Using of assonance adds music of its own to the poetry. There are some examples: the sound " $i$ " carries on in the line 16 through "In $\underline{i t s}$ autumn tint of gold".

Another striking example of the assonance we observe in the $10^{\text {th }}$ line: "Of a most stormy life - was drawn"; in the $13^{\text {th }} 14^{\text {th }}$ and $15^{\text {th }}$ stanzas:

From the torrent, or the fountain,

From the red cliff of the mountain,

From the sun that round me rolled

Through the assonance and alliteration E.Poe imitates the sounds of nature and raises the reader's imagination. Poet tries to juxtapose the only man to the picturesque nature and in such a way intecifies his solitude.

To Helen. This poem was written to a woman Poe fell in love with after Virgina's death. The woman's name was Sarah Helen Whitman who was an admiring fan of Poe's poem "The Raven". In 1845 she wrote him a poem imitated his his style from "The Raven" and even borrowing some of the phrases and rhymes. When he discovered who she was he wrote her this poem and answered her compliments and titling it "To Helen"22.

This poem consists of three stanzas, the rhyme scheme is described as ABABB.

In this poem E.Poe admires a woman, he compares her appearance and beauty with the sea, in the $1^{\text {st }}$ stanza.

With the help of assonance and alliteration the author imitates the sounds and rhythm of waves, note o's, w's in the example:

Helen, thy beauty is to me

Like those Nicean barks of yore,

That gently, o'er a perfum'd sea,

The weary way-worn wanderer bore

To his own native shore.

\footnotetext{
${ }^{22}$ Complete Works of Edgar Allan Poe. Tally Hall Press, 1997. P. 803.
} 
In the $2^{\mathrm{d}}$ stanza poet describes her appearance, her face and hair. The peculiar image is created through repetition of o's and r's, which, to our mind, resemble the exclamations of delight:

On desperate seas long wont to roam,

Thy hyacinth hair, thy classic face,

Thy Naiad airs have brought me home

To the beauty of fair Greece,

And the grandeur of old $\underline{\text { Rome }}$.

In this very stanza E.Poe uses anaphora, the $2^{\mathrm{d}}$ and $3^{\mathrm{d}}$ lines begings with "thy" in order to attaract our attention, and intensify the impression.

E.Poe uses three exclamatory sentences in the $3^{\mathrm{d}}$ stanza, which is the climax of the poem. Using of assonance and consonance adds music to these lines, note i's, o's and l's:

Lo! in that little window-niche

How statue-like I see thee stand!

The folded scroll within thy hand-

A Psyche from the regions which

Are Holy land!

The feelings of love always arises hidden resourses of human imagination. When one admires somebody, he sees beauty and hears sounds there, where he early didn't noitice it.

\section{CONCLUSIONS}

We came to the conclusion that is characteristic of the language of fiction syntactic repetition as an expressive device that contains bright, gradational effect. Repetition in the researched E. Poe poetry focuses attention on any particular semantic element of the utterance, or throughout the utterance. Edgar Allan Poe widely uses syntactical stylistic device repetition, through which he achieves rhythmical and melodical effect in his poems. He uses such types of repetition as: frame, refrain, alliteration, assonance, consonance, homoiotelenton, homoiptoton, anaphore, adnominatio, conduplicatio, diacope, epistrophe, mesodiplosis, palilogia, polyptoton, polysyndeton and others. We came to the conclusion that these repetitions can perform the function of enhancing expressiveness in the text, to convey value to create a sequence, duration, or monotony growth effect. In addition, they can specify expressed (tautological repetition); to be a means of stylization, character character speech and perform rhythmic function.

Poe's poems are unique and ahead of his time both on themes and beauty seeking, so some critics didn't agree to list Poe as a romantic poet. He found his unique inspiration and special expressing way in the pure "aesthetic form" and "endless indication". His poetry mood is a 
world of high unification between sense of hearing and vision, rhyme and rhythm, imagination and emotion. It is a world of pure beauty, a world of music, a world without hatred and fear. All in all, he is a great writer and poet of his time.

\section{SUMMARY}

The main purpose of this study is to investigate the stylistic poetry features of the American poet-writer Edgar Poe. Edgar Poe is known worldwide for his brilliant short stories. However, he began his career as a poetry writer. The first books he published were collections of his own poetry. Most scholars of Edgar Poe's work are inclined to believe that the characters and events described by the writer in his writings are autobiographical. The prototypes of Edgar Poe's protagonists are his mother, sister, wife, friends and colleagues, or just people the writer has encountered in everyday life, events he has witnessed or experienced.

The main poetic principles of E.Po are the following: poetry cannot be too large in scope, true poetry is poetry written for the sake of poetry, poetry does not necessarily correlate with everyday truth, immortal, E. Po considered feeling beautiful, which in turn It encourages the creation of poetry, the corresponding poetry is music, although poetic feelings can be realized through painting, sculpture, architecture, landscapes, dance, and other forms of art.

In his poetry, Edga Poe makes extensive use of such stylistic expressiveness as repetition, and skillfully manipulates it. Due to the widespread use of different types of repetition of Poe's poetry, there is a special expressiveness, rhythm, aesthetics. The repetitions of the vowels and the consonants add to the musicality, to imitate the sounds of nature, and thus excite the reader's imagination, create the effect of presence.

The works of the American poet-writer Edgar Po are not lost their relevance today.

\section{REFERENCES}

1. Арнольд И.В. Стилистика. Современный английский язык:Учебник для вузов. 5-е издание, вып., дополн. М.: 2002. 384 с.

1. Зырянова Т. Средства создания звуковой экспрессии. Зеленая лампа. 2004. № 1. URL: http://lamp.semiotics.ru/express.htm (дата звернення: 27.09.2019)

2. Касарес Х. Введение в современную лексикографию. М., 1959. $450 \mathrm{c}$

3. Колчева Т.В. Мистицизм поэтического ритма Эдгара По в восприятии К. Бальмонта: (На основе анализа стихотворения Э. По 
«The Bells» и перевода К. Бальмонта «Колокольчики и колокола»). Русский символизм и мировая культура. М., 2004. Вып. 2. С. 68-78.

4. Коноваленко А.Г. Баллады Э. По в переводе В. Брюсова: автореф. дис. ... канд. филол. наук / Том. гос. ун-т. Томск, 2007. 26 с.

5. Коробейникова О. Ю. Языковая эквивалентность текста как фактор организации художественного текста. дис. ... канд. филол. наук : 10.02.01 «Русский язик». СПб., 1996. 260 с.

6. Михина М.В. Эдгар Аллан По, новеллист, поэт, теоретик, и французская поэзия второй половины XIX века: автореф. дис. ... канд. филол. наук / МГУ им. М.В. Ломоносова. М., 1999. 16 с.

7. Сенкевич М. П. Стилистика научной речи и литературное редактирование научных произведений. М.: Высшая школа, 1984. $350 \mathrm{c}$.

8. Ситников К. Симфония колоколов и колокольчиков : [стихи Э.А. По «Колокола» в рус. пер.]. Литературная учеба. 2000. № 1. C. 206-224.

9. Ars Rhetorica. Edited by W. D. Ross. OCT. Oxford: Oxford UP, 1959.

10. Cambridge Idioms Dictionary (2006), $2^{\text {nd }}$ ed. Cambridge University Press. Retrieved from: http://www.cambridge.org

11. Complete Works of Edgar Allan Poe. Tally Hall Press, 1997. $1298 \mathrm{p}$.

12. Leech G. Short M. Style in fiction: a linguistic guide to English fictional prose. London : Longman, 1981. 450 p.

13. Poe E. A. The Works of the Late Edgar Allan Poe. Vol III. New York: J.S. Redfield, Clinton Hall, 1850.

14. Weils K. A. A Dictionary of Stylistics. London, 1997. 496 p.

\section{Information about the author:}

Ivanchenko M. Yu.,

Candidate of Philological Science, Assosiate Professor at the Department of Foreign Languages and Translation,

Lviv State University of Life Safety 35, Kleparivsjka str., Lviv, 79000, Ukraine 